\title{
Clinical Characteristics and Positivity Rate of COVID- 19 in Semarang, Central Java, Indonesia
}

\author{
Maulina Istighfaroh ${ }^{1}$, Lukman Fauzi² \\ \{ faramaulina511@gmail.com ${ }^{1}$, lukman.ikm@mail.unnes.ac.id² \\ Universitas Negeri Semarang, Semarang, Indonesia
}

\begin{abstract}
Data regarding the positivity rate and clinical characteristics of COVID-19 in Semarang was still rare. Even though, the data was needed to make policies in dealing with COVID-19 pandemic. This study will present data of positivity rate and clinical characteristics of COVID-19 in Semarang. The data sources used in this study were secondary data from scientific journals and official government news. On March 5, 2021, the number of COVID-19 in Semarang was 431 patients with 219 of them were males $(50,81 \%)$ and 212 were females $(49,19 \%)$. If grouped by age, patients aged $20-54$ years had the highest number with 239 patients $(55,45 \%)$. Then the positivity rate of COVID-19 in Semarang on March 5, 2021 was 19,97\%. The positivity rate of COVID-19 in Semarang was very high if compared to the WHO standard which is only 5\%. In Semarang, men and young people were more susceptible to exposure to COVID-19.
\end{abstract}

Keywords: COVID-19, clinical characteristics, and positivity rate.

\section{Introduction}

In March 11, 2020, World Health Organization (WHO) declared COVID-19 or Coronavirus Disease-2019 as a global pandemic [1]. COVID-19 is a disease that occurred by a virus called Severe Acute Respiratory Syndrome Coronavirus 2 (SARS-CoV2). SARS-CoV2 is a new type of virus from the Coronavirus family that was first discovered in Wuhan, China in December 2019. This disease affected in the respiratory tract of human and originally this SARS-CoV2 was transmitted form animals to human, and now SARS-CoV2 transmitted from human to human. Because the transmitted of COVID-19 was from human to human and spreads via droplets, so the spread of COVID-19 is very quickly due to human mobilities [2] [3].

A patient who is confirmed positive of COVID-19 is someone who has tested positive for the COVID-19 virus as proven by RT-PCR laboratory examination. This is accordance with KMK-RI No. HK.01.07/MENKES/413/2020 concerning Guidelines for the Prevention and Control of CORONA VIRUS DISEASE (COVID-19) [4]. Confirmatory cases can be divided into two, namely confirmation cases with symptoms (symptomatic) and confirmation cases without symptoms (asymptomatic) [2] [3]. Confirmed patients with symptoms will be directed to seek treatment at a health facility, while for patients without symptoms will be self-isolated. The main symptoms that occur in patients who are positive for COVID-19 are fever, dry cough, dyspenia, fatigue, muscle aches, and headache. Apart from these symptoms, other symptoms of the gastrointestinal tract and neurological manifestations were also reported [5].

The COVID-19 pandemic has been running for more than a year, but the positive number of COVID-19 is still increasing every day. As of March 15, 2021, in the world there were 
78.412.817 confirmed cases of COVID-19 and 1.740.865 cases died [6]. Meanwhile in Indonesia there were 1.425 .044 positive cases, 1.249 .947 recovered cases, 38.573 cases died, and 136.524 active cases [7]. The number of positive COVID-19 in Indonesia has made Indonesia ranked $19^{\text {th }}$ from 192 countries that exposed to COVID-19 in the world [8]. In addition, Indonesia ranks first with the highest active cases of COVID-19 among countries in Southeast Asia [9].

The number of confirmed cases of COVID-19 in Indonesia has spread across 34 provinces [2] [3]. Central Java is in the $3^{\text {rd }}$ rank of the highest positive daily cases in Indonesia with the addition of cases on March 15, 2021 was 700 patients [7] [10]. So that the total active cases in Central Java as of March 15, 2021 were 6.033 patients with Semarang in the first rank with the highest number of active cases [2] [10] [11]. On March 5, 2021, the number of active COVID19 cases in Semarang reached 431 patients with 219 patients were males and 212 patients were females [12]. Data regarding the positivity rate and clinical characteristics of COVID-19 in Semarang is still rare. Even though, the data is needed to make policies in dealing with COVID19 pandemic. So, this study will present data of positivity rate and clinical characteristics of COVID-19 in Semarang. Hopefully that the results of this study will provide information to the public regarding the COVID-19 case in Semarang, Central Java.

\section{Materials and methods}

This research uses descriptive research design. The data sources used in this research are secondary data from the recording of COVID-19 patients reported to the Department of Health of Semarang, scientific journals, and official government news. The data source to analyze clinical characteristics of COVID-19 were data from COVID-19 patients in Semarang until March 5, 2021 which is the number of COVID-19 patients were 431 patients. Then the data source to analyze the positivity rate of COVID-19 in Semarang was data from the number of people who confirmed positive for COVID-19 compared to the number of people who were tested for COVID-19. The positivity rate of COVID-19 in Semarang will be shown monthly from November 2020 until March 2021.

\section{Results}

\subsection{Distribution of active cases of COVID-19 by age and gender}

The total active cases of COVID-19 in Semarang, Central Java, Indonesia in March 5, 2021 was 431 patients. The distribution by gender show that from 431 patients, 219 patients $(50,81 \%)$ was males and 212 patients $(49,19 \%)$ was females. Then the distribution by age show that from 431 patients, $6(1,39 \%)$ patients aged $6-9$ years, $17(4,11 \%)$ patients aged $10-19$ years, 239 $(55,45 \%)$ patients aged $20-54$ years, $123(28,53 \%)$ patients aged $55-69$ years, and 46 $(10,67 \%)$ patients aged more than 70 years [12]. The data shows that there are more cases in male than in female. Besides that, COVID-19 is also infected more young people which aged between $20-54$ years. The distribution of active cases of COVID-19 in Semarang by age and gender shows in the fig. 1 . 


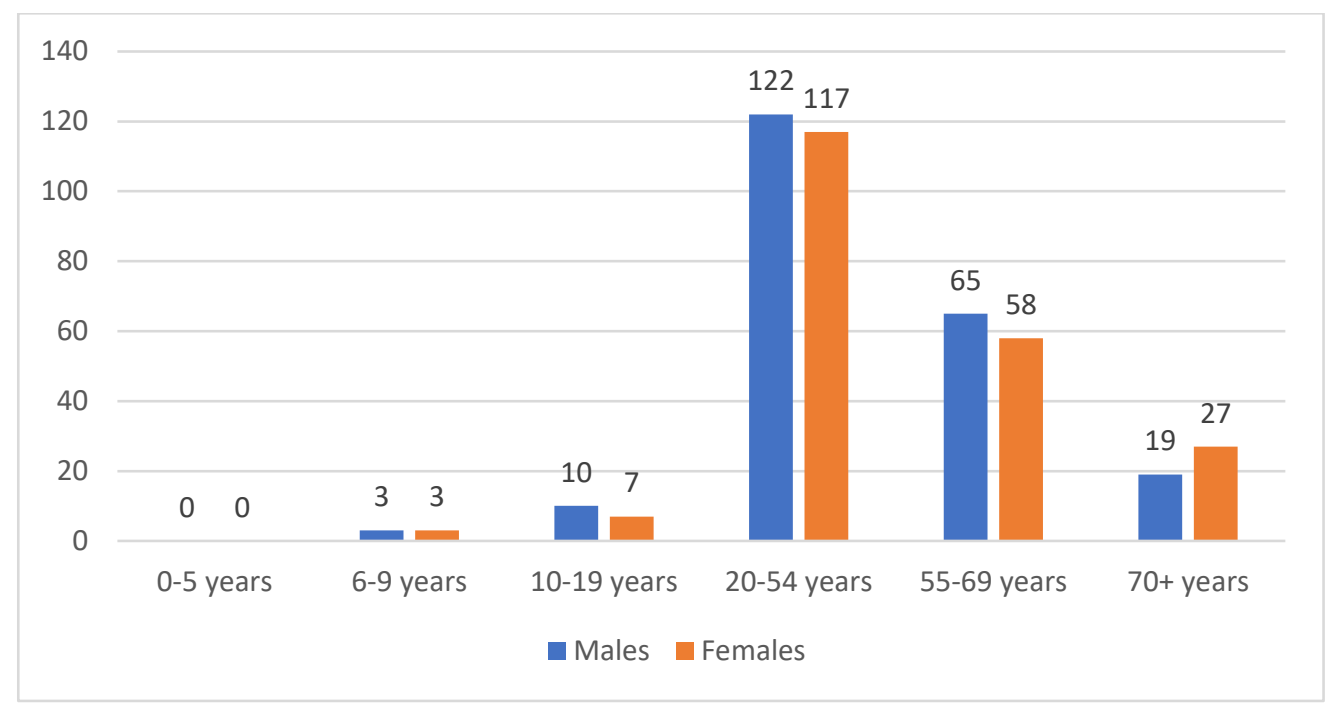

Fig. 1. Distribution of active cases of COVID-19 by age and gender

\subsection{Distribution of active cases of COVID-19 by the origin}

Active Cases of COVID-19 in Semarang spread in 16 districts with 117 sub-districts and there are 98 patients of COVID-19 who are outside Semarang but the data is included in the data of active cases of COVID-19 in Semarang. The distribution of active cases of COVID-19 by the origin is presented in table 1 . The table shows that the highest active cases of COVID-19 are from outside Semarang with 98 cases $(22,54 \%)$. Followed by the District of Tembalang with 42 cases $(9,66 \%)$. Then followed by the District of Pedurungan with 38 active cases $(8,81 \%)$. The lowest active cases of COVID-19 were from District of Tugu with 5 cases $(1,15 \%)$ [12].

Table 1. Distribution of active cases of COVID-19 by the origin

\begin{tabular}{lcc}
\hline \multicolumn{1}{c}{ Sub-district } & $\begin{array}{c}\text { Number of } \\
\text { Active Cases }\end{array}$ & Percentage (\%) \\
\hline District of North Semarang & 1 & 0,23 \\
Plombokan & 2 & 0,46 \\
Dadapsari & 8 & 1,84 \\
Kuningan & 2 & 0,46 \\
Panggung Kidul & 2 & 0,46 \\
Bandarharjo & 4 & 0,92 \\
Panggung Lor & 3 & 0,69 \\
Purwosari & 3 & 0,69 \\
Tanjungmas & 11 & 2,53 \\
Bulu Lor & & \\
District of East Semarang & 1 & 0,23 \\
Kebonagung & 3 & 0,69 \\
Rejosari & 1 & 0,23 \\
Bungangan & 3 & 0,69 \\
Sarirejo & &
\end{tabular}


District of South Semarang

Peterongan

Lamper Tengah

Pleburan

0,46

Mugassari

Barusari

Randusari

Lamper Lor

0,69

Bulustalan

0,23

Lamper Kidul

District of Central Semarang

Jagalan

Brumbungan

Purwodinatan

Sekayu

Pekunden

Kembangsari

Kranggan

Karang Kidul

Pindrikan Kidul

District of West Semarang

Bongsari

Salamanmloyo

Krapyak

Ngemplak Simongan

Kembangarum

Gisikdrono

Cabean

0,46

Kalibanteng Kulon

0,23

Krobokan

Karangayu

Bojong Salaman

0,46

Tawang Mas

Manyaran

0,23

0,69

Tawang Sari

District of Gayamsari

Pandean Lamper

Kaligawe

0,69

Gayamsari

Sambirejo

1,15

0,92

Tambakrejo

District of Candisari

Jomblang

Karanganyar Gunung

0,92

Tegalsari

1,15

Candi

Jatingaleh

1,15

0,69

Wonotinggal 


\section{District of Ngaliyan}

Kalipancur

Wates

Wonosari

Tambakaji

Purwoyoso

Gondoriyo

Bringin

Podorejo

Ngaliyan

District of Banyumanik

Padangsari

Srondol Kulon

Srondol Wetan

Banyumanik

Pudak Payung

Ngesrep

Pedalangan

Tinjomoyo

Sumurboto

District of Genuk

Bangetayu Wetan

Bangetayu Kulon

Gabangsari

Genuksari

District of Tembalang

Jangli

Meteseh

Tandang

Kramas

Sendangmulyo

Sambiroto

Tembalang

Mangunharjo

Rowosari

Sendangguwo

Kedungmundu

District of Gajahmungkur

Karangrejo

Petompon

Sampangan

Lempongsari

Gajahmungkur

Bendan Duwur

District of Pedurungan

Kalicari

Tlogosari Kulon

Palebon

Pedurungan Tengah 


\begin{tabular}{lcc} 
Gemah & 3 & 0,69 \\
Pedurungan Lor & 2 & 0,46 \\
Tlogomulyo & 5 & 1,15 \\
Muktiharjo Kidul & 4 & 0,92 \\
Tlogosari Wetan & 2 & 0,46 \\
District of Gunungpati & & \\
Sukorejo & 5 & 1,15 \\
Patemon & 1 & 0,23 \\
Plalangan & 2 & 0,46 \\
Sadeng & 3 & 0,69 \\
Gunungpati & 2 & 0,46 \\
Mangunsari & 2 & 0,46 \\
Pongangan & 1 & 0,23 \\
District of Tugu & & \\
Tugurejo & 2 & 0,46 \\
Jrakah & 3 & 0,69 \\
District of Mijen & & \\
Jatisari & 2 & 0,46 \\
Wonolopo & 2 & 0,46 \\
Mijen & 1 & 0,23 \\
Bubakan & 1 & 0,23 \\
Other Regency & 98 & 22,54 \\
Total & & 100,00 \\
\hline
\end{tabular}

\subsection{The symptoms of COVID-19 in Semarang, Central Java, Indonesia}

The main symptoms of COVID-19 are cough, fever, and dyspnia [13]. In some cases, other symptoms have been reported such as diarrhea, fatigue, shivering, colds, nausea, sore throat, asphyxiate, headache, and stomach pain [14] [15]. Apart from symptomatic patients, nearly 50\% of the COVID-19 patients in Semarang are reported to the asymptomatic [16] [17]. The Semarang City Health Office also stated that there were several COVID-19 who experienced happy hypoxia [12]. Happy Hypoxia is a condition where patients have low oxygen saturations as measured by pulse oximetry $\left(S_{p o 2}<90 \%\right)$, but where no in significant respiratory distress and often appear clinically well [18] [19] [20]. Even so, the symptoms of COVID-19 in Semarang are quite varied but the majority experience cough and fever.

\subsection{Positivity rate of COVID-19 in Semarang, Central Java, Indonesia}

The trend of positivity rate of COVID-19 in Semarang is shown in fig. 2. The positivity rate of COVID-19 in Semarang in last five months has never been less than 15\%. The highest number of positivity rate from November 2020 until March 2021 in Semarang is in February 2021 with $20,02 \%$, it means that every 100 people tested for COVID-19, at least there are 20 people confirmed to COVID-19. Then the lowest number of positivity rate from last five months in Semarang is in November 2020 with 16,65\% [12]. Which is the average of positivity rate of COVID-19 in Semarang from last five months was $18,36 \%$. 


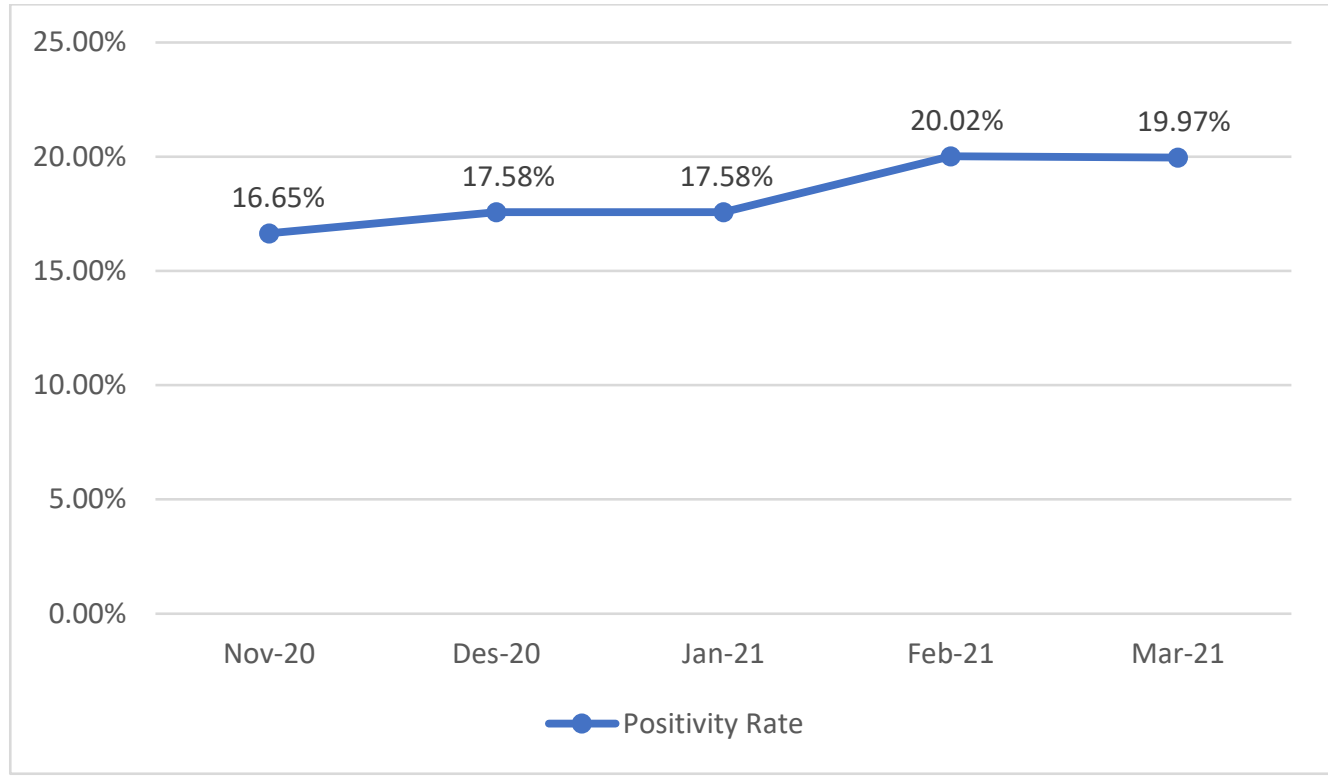

Fig. 2. Positivity rate of COVID-19 in Semarang in last five months

\section{Discussion}

The number of active cases of COVID-19 in Semarang, Central Java, Indonesia until March 5, 2021 was 431 patients. In the cases based on gender, the number of males were 219 patients or $50,81 \%$ while for females were 212 patients or $49,19 \%$. Similar to the distribution of COVID19 patients based on sex in Indonesia, where of the total cases that occurred in Indonesia, 57\% were male patients and $43 \%$ were female [2] [21]. This is also the same as research with case studies in China, where of the 44.672 confirmed cases of COVID-19, 51,4\% were male and $48,6 \%$ were female [2] [3] [22]. However, this is in contrast to the study conducted in Zhejiang, where 59,34\% of COVID-19 patients were female and 40,66\% were male [23]. Then based on age, the number of COVID-19 patients in Semarang aged 0-5 years was 0 patients, aged 6-9 years were 6 patients or 1,39\%, aged 10-19 years were 17 patients or 3,94\%, aged 20-54 years were 239 patients or 55,45\%, aged 55-69 years were 123 patients or $28,53 \%$, and aged $70+$ years were 46 patients or $10,67 \%$. The same thing happened in a study in Beijing with the highest number of patients of COVID-19 at the age of 13-44 years (adults) with $42,7 \%$ of the total patients [24].

There are 16 districts in Semarang, Central Java, Indonesia with the highest active cases of COVID-19 are residents of Semarang who are outside Semarang with 98 cases (22,54\%). Based on the Decree of the Minister of Health of Republic of Indonesia Number HK.01.07/MENKES/413/2020 concerning Guidelines for the Prevention and Control of Coronavirus Disease 2019 (COVID-19), when a new confirmed case of COVID-19 is found, the variables that must be completed when recording the notification of case discovery are: name, NIK, gender, address, mobile contact number that can be contacted, date of onset (symptoms appear), symptoms related to COVID-19, history (contact/travel/none), 
accompanying conditions, epidemiological status (suspect/probable/confirmation), and actions (referral/care/independent isolation). Address variable is filled with residential address in the last 14 days [4]. This shows that 98 COVID-19 patients outside Semarang are people who in the last 14 days have been in Semarang but were confirmed positive for COVID-19 outside the city of Semarang.

The main symptoms of COVID-19 are cough, fever, and dyspnia. In addition, there are several other symptoms that have been reported in COVID-19 patients, such as diarrhea, fatigue, shivering, colds, nausea, sore throat, asphyxiate, headache, and stomach pain. Apart from symptomatic patients, nearly 50\% of the COVID-19 patients in Semarang are reported to the asymptomatic. Even so, the symptoms of COVID-19 in Semarang are quite varied but the majority experience cough and fever. Other studies have shown that the highest symptoms seen in patients of COVID-19 were fever with $91,3 \%$, followed by cough with $67,7 \%$, fatigue with $51 \%$, and dyspnia with 30,4\% [25]. The most common symptoms in COVID-19 patients are symptoms of acute respiratory disorders such as fever, cough, and asphyxiate [26].

Positivity rate of COVID-19 in Semarang from November 2020 until March 2021 has never been less than 15\%. During the last five months, the highest positivity rate was in February 2021 with $20,02 \%$, meaning that for every 100 people tested for COVID-19 at least 20 people were confirmed positive for COVID-19. Then followed by March 2021 with a positivity rate of $19,97 \%$. The positivity rate for COVID-19 in Semarang needs attention because it has far exceeded the standard limit for the positivity rate of COVID-19 set by World Health Organization (WHO), which is no more 5\% [27]. The method of calculating this positivity rate is by dividing the number of patents confirmed positive for COVID-19 by the number of people who have tested for COVID-19 and then multiplying by 100.

\section{Conclusion}

The number of confirmed cases of COVID-19 in Indonesia has spread across 34 provinces. Central Java is in the 3rd rank of the highest positive daily cases in Indonesia. In Central Java, Semarang ranks first with the highest number of active cases. The active cases of COVID-19 in Semarang in March 5, 2021 were 431 patients with 219 patients (50,81\%) were males and 212 patients $(49,19 \%)$ were females. Based on the age, the highest number of active cases of COVID-19 in Semarang is at the age of 20-54 years or in adulthood with 239 patients or 55,45\%. Active cases of COVID-19 in Semarang spread in 16 districts with 117 sub-districts, with the highest active cases of COVID-19 are from residents outside Semarang with 98 cases $(22,54 \%)$. Followed by the District of Tembalang with 42 cases $(9,66 \%)$. Then the lowest active cases of COVID-19 were from District of Tugu with 5 cases $(1,15 \%)$. Based on symptoms, the symptoms that often appear in COVID-19 patients in Semarang are cough, fever, and dyspnia. However, nearly $50 \%$ of COVID-19 patients repost no symptoms. Then, the positivity rate of COVID-19 in Semarang requires attention because the positivity rate was far exceed the standard limit for the positivity rate for COVID-19 set by WHO, which is the average from last five months was $18,36 \%$. 


\section{References}

[1] World Health Organization, "Coronavirus Disease (COVID-19) Pandemic," World Health Organization, Indonesia, 2020.

[2] D. Sutiningsih, Epidemiologic and Clinical Characteristics of Patients with Covid-19 in Central Java, Indonesia, in E3S Web of Conferences 202, 12014, Central Java, 2020.

[3] H. Surendra, I. R. Elyazar, B. A. Djaafara and et.al, Clinical Characteristics and Mortality Associated with COVID-19 in Jakarta, Indonesia: A Hospital-based Retrospective Cohort Study, The Lancet Regional Health - Western Pacific. 2021; 9: 100108.

[4] Health Ministry of Indonesia, "Keputusan Menteri Kesehatan Republik Indonesia Nomor HK.01.07/MENKES/413/2020," 2020. [Online]. Available: https://covid19.go.id/p/regulasi/keputusan-menteri-kesehatan-republik-indonesia-nomorhk0107menkes4132020. [Accessed 2020].

[5] N. I. Fitriani, Tinjauan Pustaka COVID-19, Virologi, Patogenesis, dan Manifestasi Klinis, Jurnal Medika Malahayaiti. 2020; 4: 3.

[6] A. Susilo, C. M. Rumende, C. W. Pitoyo and et.al, Coronavirus Disease 2019: Review of Current Literatures, Jurnal Penyakit Dalam Indonesia. 2020; 7(1): 45-46.

[7] Health Ministry of Indonesia, "Data Sebaran COVID-19 Indonesia," https://covid19.go.id/, 2021.

[8] I. Wahidah and et.al, COVID-19 Pandemic: Analysis of Government and Community Planning in Various Prevention Measures, Jurnal Manajemen dan Organisasi (JMO). 2020; 11: 3.

[9] Sekretariat Nasional ASEAN - Indonesia, "Indonesia Masih Catatkan Angka Kematian Akibat COVID-19 Tertinggi di Asia Tenggara," 2020. [Online]. Available: http://setnas-asean.id. [Accessed March 2021].

10] Dinas Kesehatan Jawa Tengah, "Sebaran Kasus COVID-19 di Jawa Tengah," Tanggap COVID-19 Provinsi Jawa Tengah, Jawa Tengah, 2021

[11] D. Handayani, D. R. Hadi, F. Isbaniah, E. Burhan and H. Agustin, Penyakit Virus Corona 2019," Jurnal Respirologi Indonesia. 2020; 4(2).

[12] Dinas Kesehatan Kota Semarang, "Kota Semarang Siaga Corona," Dinas Kesehatan Kota Semarang, Semarang, 2021.

[13] Yuliana, Penyakit Virus Corona 2019, Wellness and Healthy Magazine. 2020; 2: 1

[14] F. Setiawan, H. Puspitasari, J. Sunariani and A. Yudianto, MOLECULAR REVIEW COVID19 FROM THE PATHOGENESIS AND TRANSMISSION ASPECT, Jurnal Kesehatan Lingkungan. 2020; $12: 1$.

[15] K. Karyono, R. Rohadin and D. Indriyani, PENANGANAN DAN PENCEGAHAN PANDEMI WABAH VIRUS CORONA (COVID-19) KABUPATEN INDRAMAYU, Jurnal Kolaborasi Resolusi Konflik. 2020; 2: 2.

[16] K. Yuki, M. Fujiogi and S. Kautsogiannaki, COVID-19 pathophysiology: A review, Elsevier. 2020; 215.

[17] R. Weissleder, H. Lee, J. Ko and M. J. Pittet, COVID-19 diagnostics in context, AAAS Journal. 2020; $12: 546$

[18] J. Couzin-Frankel, The mystery of the pandemic's happy hypoxia, AAAS Journal. 2020; 368: 6490.

[19] A. Widysanto, L. H. S. Titis D. Wahyuni and et.al, Happy hypoxia in critical COVID-19 patient: A case report in Tangerang, Indonesia, The Physiological Society. 2020; 8: e14619.

[20] D. Sahu and T. Agrawai, Is it the COVID-19 happy hypoxia syndrome or the COVID 19 infodemic syndrome?, Elsevier Public Health Emergency Collection. 2020; 14: 1399.

[21] F. Ibrahim, A. Natasha, Y. Saharman and P. Sudarmono, Preliminary report of COVID-19 testing: experience of the clinical microbiology laboratory Universitas Indonesia, Jakarta, Indonesia, Elsevier. 2020; 37: 100733.

[22] The Novel Coronavirus Pneumonia Emergency Response Epidemiology Team, The Epidemiologic Characteristics of an Outbreak of 2019 Novel Coronavirus Disease (COVID-19), China CDC Weekly, China, 2020. 
[23] Q. Q. G, -B. Y. N, F. Ding and et.al, Epidemiologic and Clinical Characteristics of 91 Hospitalized Patients with COVID-19 in Zhejiang, China: a retrospective, multi-centre case series, Oxford University Press. 2020; 10: 1093.

[24] S. Tiana, N. Hub, J. Loua and et.al, Characteristics of COVID-19 Infection in Beijing, Elsevier. 2020; 10: 1016.

[25] J. Yang, Y. Zheng and X. Gou, Prevalence of Comorbidities and Its Effects in Patients Infected with SARS-CoV-2: a systematic review and meta-analysis, Elsevier. 2020.;. 3: 017.

[26] M. J. Nasiri, S. Haddadi, A. Tahvildari and et.al, COVID-19 Clinical Characteristics, and SexSpecific Risk of Mortality: Systematic Review and Meta-Analysis, Frontiers in Medicine. 2020; 10: 3389.

[27] World Health Organization, "Coronavirus Disease 2019 (COVID-19) Situation Report 11," World Health Organization , 2020. 